\title{
Molecular Pathogenesis of Alzheimer's Disease: An Update
}

\author{
Alfredo Sanabria-Castro Ileana Alvarado-Echeverría Cecilia Monge-Bonilla \\ Research Unit, Hospital San Juan de Dios, Costa Rican Social Security Fund (CCSS), San José, Costa Rica
}

\section{Keywords}

Alzheimer's disease · Dementia · Amyloid · Neurobiology · Pathogenesis · Review

\begin{abstract}
Dementia is a chronic or progressive syndrome, characterized by impaired cognitive capacity beyond what could be considered a consequence of normal aging. It affects the memory, thinking process, orientation, comprehension, calculation, learning ability, language, and judgment; although awareness is usually unaffected. Alzheimer's disease (AD) is the most common form of dementia; symptoms include memory loss, difficulty solving problems, disorientation in time and space, among others. The disease was first described in 1906 at a conference in Tubingen, Germany by Alois Alzheimer. One hundred and ten years since its first documentation, many aspects of the pathophysiology of AD have been discovered and understood, however gaps of knowledge continue to exist. This literature review summarizes the main underlying neurobiological mechanisms in $A D$, including the theory with emphasis on amyloid peptide, cholinergic hypothesis, glutamatergic neurotransmission, the role of tau protein, and the involvement of oxidative stress and calcium.

๑) 2017 S. Karger AG, Basel
\end{abstract}

\section{Search Strategy and Selection Criteria}

A literature review was conducted in January 2016 using PubMed, Ovid, and Science Direct with the following descriptors: Alzheimer's disease (AD), neurobiology, pathology, review. Results obtained ranged between 150 and 2,200 records after the combination of different keywords. Scientific publications between 1996 and 2015 either in English or Spanish, discussing the neuromolecular hypotheses of AD were selected. Papers concerning clinical presentation, diagnostic methods, and treatment were excluded.

Alzheimer's disease (AD) was first described in 1906 at a conference in Tubingen, Germany by Alois Alzheimer [1], as a "peculiar severe disease process of the cerebral cortex." In recent times, AD is considered a chronic or progressive syndrome, characterized by impaired cognitive capacity beyond what could be considered a consequence of normal aging; that affects the memory, thinking, orientation, comprehension, learning, language, and judgment. More than one hundred years have passed since the first pathophysiological aspects of AD were described. Neurobiological mechanisms underlying $\mathrm{AD}$ have been a key element in the understanding of the pathology, currently the most important alterations identi-

\section{KARGER}

(c) 2017 S. Karger AG, Basel

E-Mail karger@karger.com

www.karger.com/aon
Alfredo Sanabria-Castro

Research Unit, Hospital San Juan de Dios Costa Rican Social Security Fund (CCSS)

Paseo Colón, Streets 14-20 San José 10103 (Costa Rica)

E-Mail asccheo@yahoo.com 
fied can be explained through: the amyloid peptide theory, the cholinergic hypothesis that includes glutamatergic neurotransmission alterations, the role of tau protein, and the involvement of oxidative stress (OS) and calcium.

\section{The Cholinergic Hypothesis}

At a molecular level, the cholinergic hypothesis is the first and most studied approach that describes $\mathrm{AD}$ pathophysiology. It was defined more than 30 years ago as a primary degenerative process capable of selectively damaging groups of cholinergic neurons in the hippocampus, frontal cortex, amygdala, nucleus basalis, and medial septum, regions and structures that serve important functional roles in conscious awareness, attention, learning, memory, and other mnemonic processes [2]. This selective alteration generates a downregulation of cholinergic markers such as acetyltransferase and acetylcholinesterase that associate with the onset of cognitive impairment $[3,4]$; through the existence of proportionality between the decrease in cholinergic markers, the density of neurofibrillary alterations, and the severity of the pathology.

The main findings supporting this premise are the fact that non-selective muscarinic antagonists such as scopolamine-induced cognitive impairment, favor the production of beta-amyloid peptide and decrease the activity of $a$-secretase [5]. Some triterpenoid saponins have shown to reduce scopolamine-induced amnesia [6-8] and non-selective and selective muscarinic agonists have shown to improve learning and memory. Selective M1 muscarinic agonists are a pivotal target that link major hallmarks of AD. The exact molecular mechanisms of the effect of cholinergic drugs in learning and memory, and their clinical treatment viability are still being studied [912].

This hypothesis was reinforced through immunohistochemical, neuroimaging, and other analyses that revealed: a decrease in the number and density of nicotinic receptors in $\mathrm{AD}$ patients (mainly a $4 \beta 2$ subtype), a reduced expression of $\alpha 3, \alpha 4$, and $\alpha 7$ subunits at cortex and hippocampus, and a decline in the binding ability of $\alpha 7$ hippocampal and a4 cortical receptors [13-15].

The main alterations in cholinergic neurons considered in this hypothesis are: choline uptake, impaired acetylcholine release, deficits in the expression of nicotinic and muscarinic receptors, dysfunctional neurotrophin support, and deficits in axonal transport [16-18]. Recent studies have shown that amyloid $\beta$ interacts with cholinergic receptors affecting their function [19].

Molecular Pathogenesis of AD:

An Update
Because the cholinergic and glutamatergic systems significantly interact during neurotransmission alterations in the glutamatergic, signaling has been associated with cholinergic disruptions found in $\mathrm{AD}$ [20], an aspect that enhances cholinergic hypothesis. This postulate dictates that acetylcholine and its receptors, especially $(\alpha 7)_{5}$ are considered as neuroprotective by modulating glutamatemediated neuronal excitability $[21,22]$. In $\mathrm{AD}$ abnormalities in glutamatergic, neurotransmission is initially observed at the entorhinal cortex (EC), which is followed by further neurotransmission defects in the hippocampus, amygdala, frontal cortex, and parietal cortex [23].

The physiological glutamatergic neurotransmission in the hippocampus produces a cytosolic calcium signal, which mediates synaptic plasticity phenomena such as long-term potentiation (LTP), encouraging learning and memory consolidation [24]. However, a sustained increase in calcium, sodium, and chloride ions as a result of the hyperactivation of NMDA glutamate receptors has been associated with excessive depolarization of the postsynaptic membrane, onset neurodegenerative processes and cell death [25-27]. Likewise, an increase in intraneuronal calcium as a consequence of a dysfunctional glutamatergic neurotransmission can generate a long-lasting depression in the cerebellum (LTD), with calcium overload in mitochondria, activation of nitric oxide synthesis, generation of free radicals, OS, initiation apoptosis and neuronal death [28-31].

Experimentally incubating neurons with glutamate promotes the deposit of filaments similar to neurofibrillary tangles observed in AD. Also, the exposure of neuronal cultures to amyloid $\beta$ promotes glutamate-induced neurotoxicity and regulates the expression of NMDA receptors on the membrane $[32,33]$.

At the synaptic level, the lack of enzymes responsible for the degradation of glutamate causes neuronal transporters at the neuronal and glial levels to be responsible for the reuptake of the excess of neurotransmitter [34]. In $\mathrm{AD}$, the inhibition of presynaptic and glial glutamate transport [35], the reduced activity of glutamine synthetase (converts glutamate to glutamine) [36], the discrete depolarization of neurons, and stimulation of nitric oxide production by amyloid $\beta$ [23] favor the prolonged presence of extra neuronal glutamate, and hence the continued receptor stimulation and excitotoxicity [16, 34].

The cholinergic hypothesis has served as a basis for the majority of treatment strategies and drug development approaches (acetylcholinesterase inhibitors, cholinergic precursors, cholinergic receptor agonists, allosteric cho-

Ann Neurosci 2017;24:46-54

DOI: $10.1159 / 000464422$ 


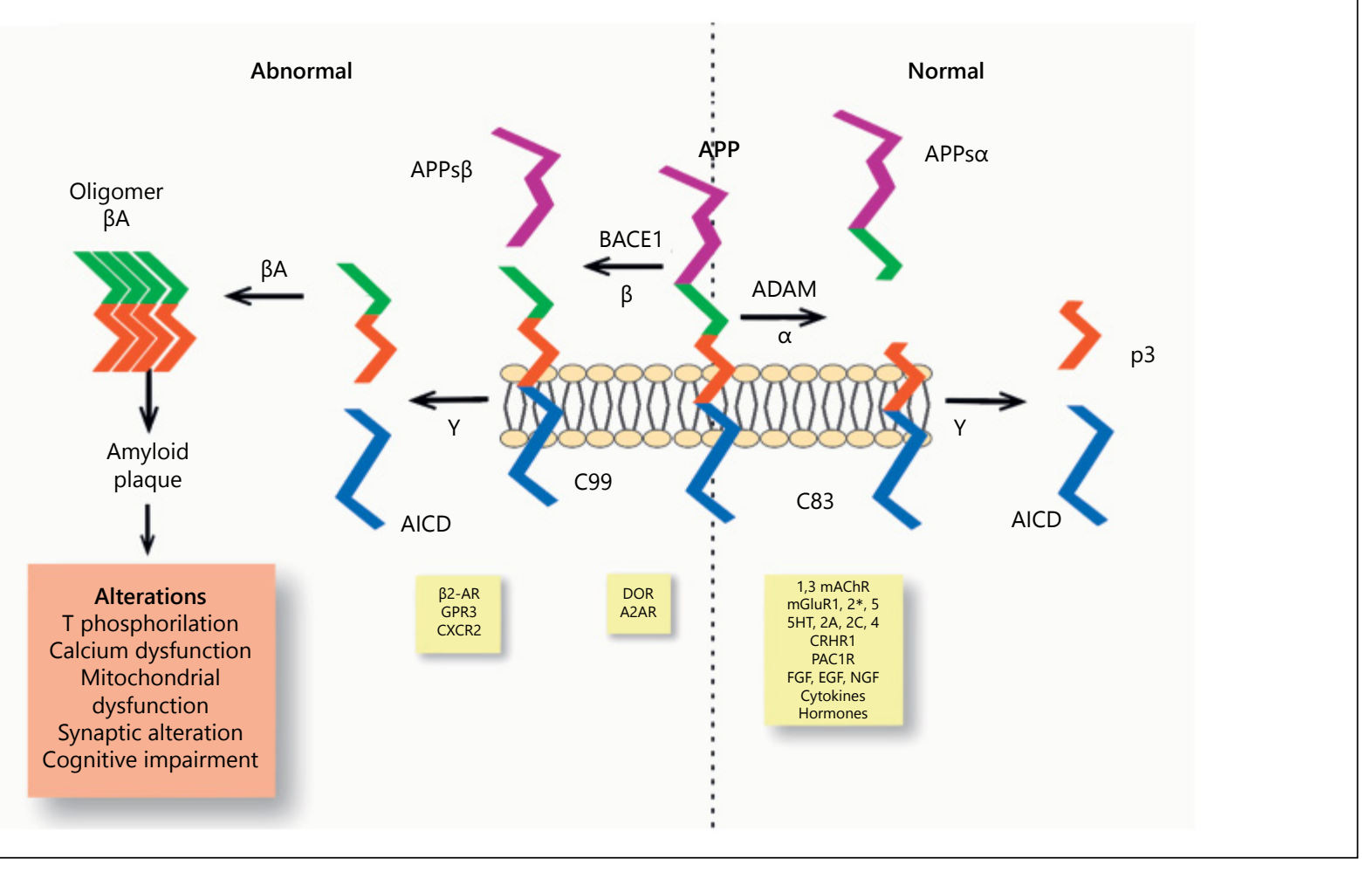

Fig. 1. Amyloidogenic and non-amyloidogenic processing of the APP. The top part of the figure shows the 2 main paths in the processing of APP, the most important elements involved, and the main alterations associated with the amyloidogenic pathway of APP. The bottom part of the figure shows potential modulators of the secretase activity (activation of receptors, growth factors, cytokines, hormones). $\alpha$, $\alpha$-secretase activity; $\beta, \beta$-secretase activity; $\gamma, \gamma$-secretase activity; BACE1, $\beta$-site - APP - cleaving enzyme $1 ; \beta A$, amyloid $\beta$ peptide; ADAM, $\alpha$-secretase; APPs $\alpha$ and APPs $\beta$, soluble portions produced by the effect of $\alpha$ - and $\beta$-secretase; C83, fragment of 83 amino acids of the carboxyl terminal portion produced by the effect of $\alpha$-secretase; C99, frag- ment of 99 amino acids of the carboxyl terminal portion produced by effect of $\beta$-secretase; p3, peptide resulting from $\gamma$-secretase; AICD, carboxy-terminal fragment referred to as the intracellular domain of APP; T, Tau protein; mAChRs, muscarinic acetylcholine receptors; $\mathrm{mGluR}$, metabotropic glutamate receptors; 5HT, serotonin receptors; CRHR1, receptor 1 of the corticotropin-releasing hormone; PAC1R, receptor 1 of pituitary adenylate cyclase; FGF, EGF, NGF, growth factors of fibroblasts, epidermis and the nervous system respectively; DOR, opioid receptor $\delta$; $\mathrm{A} 2 \mathrm{AR}$, adenosine receptor $2 \mathrm{~A} ; \beta 2-\mathrm{AR}, \beta 2$ adrenergic receptor; GPR3, receptor 3 coupled to protein G; CXCR2, chemokine receptor 2 . linergic receptor potentiators, NMDA receptor blockers) for AD. Currently there is consensus that the observed relationship between cognitive impairment and decreased cholinergic transmission in the brain plays an important role in AD but by itself does not establish definitive causation of the disease $[37,38]$.

\section{The Amyloid Hypothesis}

In the amyloid cascade hypothesis of $\mathrm{AD}$, the disease is analyzed as a series of abnormalities in the process and secretion of the amyloid precursor protein (APP), where an inequality between production and clearance of amy- loid $\beta$ is the triggering event and the most important factor; responsible for other abnormalities observed in $\mathrm{AD}$ [39]. Amyloid $\beta$ is a peptide with high resistance to proteolytic degradation. It consists of 37-43 amino acids, in which the isoforms 1-40 and 1-42 are the most common [40]. The 1-42 amyloid peptide isoform is the most hydrophobic and is considered to have the greatest toxicity [23]. Because of its physical characteristics, it often acquires the configuration of a $\beta$-pleated sheet [41], showing a greater tendency to aggregate and form the core of the amyloid plaque [42-44]. It is the main component of amyloid neuritic plaques $[43,45]$.

The processing of APP at the plasma membrane constitutes the origin of the amyloid peptide (Fig. 1). APP is
48

Ann Neurosci 2017;24:46-54 DOI: $10.1159 / 000464422$
Sanabria-Castro/Alvarado-Echeverría/ Monge-Bonilla 


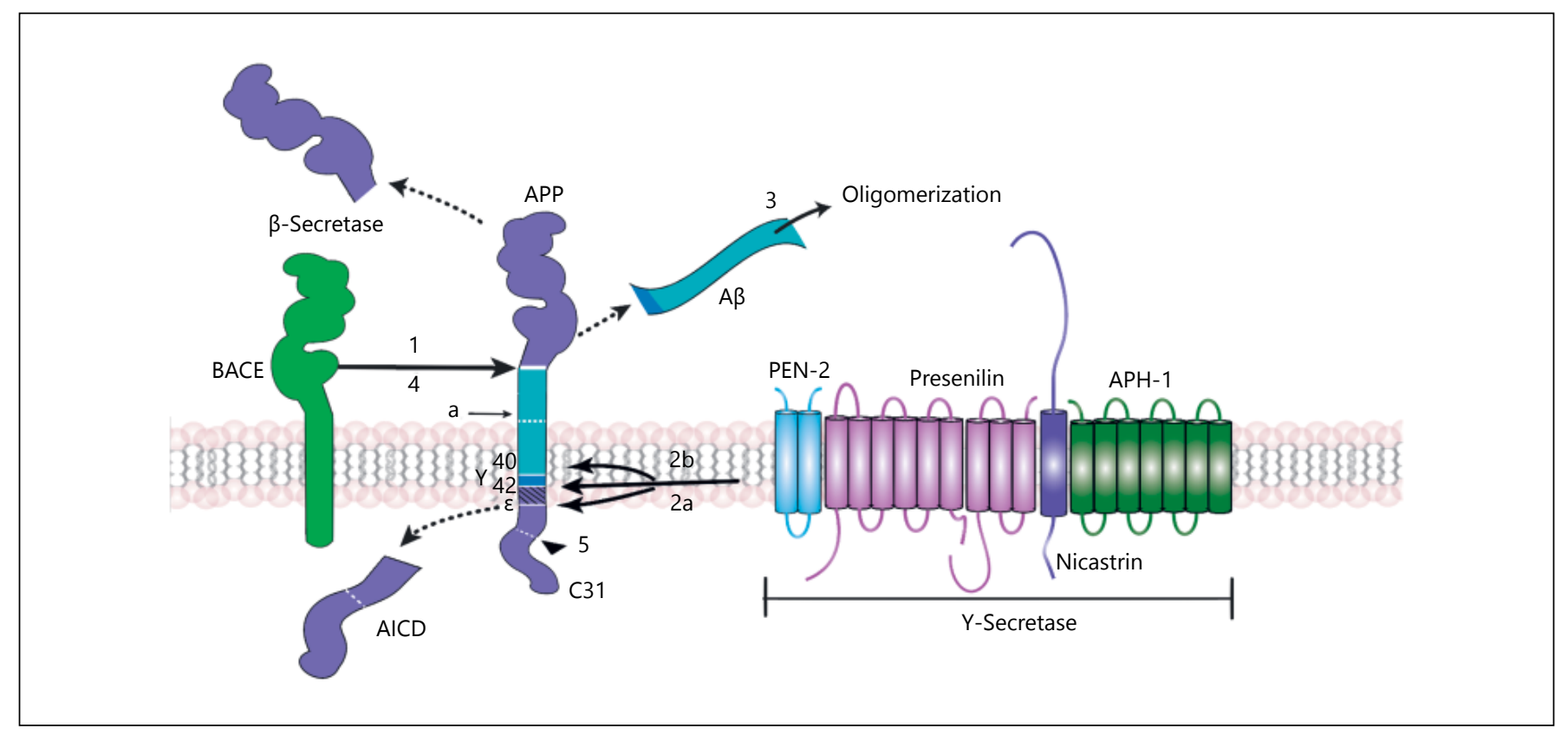

Fig. 2. Production of amyloid $\beta$ peptide from sequential proteolytic breaks of the APP. The figure shows the sequence of phases in the processing of APP in the formation of amyloid $\beta$ peptide and its oligomerization. Numbers (1, 2a, 2b, 3, 4, and 5) refer to intervention sites where the production of amyloid $\beta$ peptide could be modulated with possible therapeutic utility. $\alpha, \alpha$-secretase cut site; $\gamma, \gamma$-secretase cut site $\gamma ; \varepsilon$, cut site $\varepsilon$ of $\gamma$-secretase; BACE, $\beta$-secretase; A $\beta$, amyloid $\beta$ peptide; AICD, carboxy-terminal fragment referred to as APP intracellular domain. a transmembrane glycoprotein of type I and its specific function is unclear; however it is known that its expression is increased during cellular stress phenomena. APP processing is performed by a series of ruptures, which involves an initial breakdown by enzymes with $\alpha$-secretase activity, mainly enzymes belonging to the disintegrin and metalloprotease (ADAM) family including: ADAM10, ADAM17, and ADAM19 [45, 46]. ADAM activity can be modulated by different situations such as receptor activation, growth factors, cytokines, and hormones. The excision produced by $\alpha$-secretase leads to the formation and release of a peptide of the amino terminal portion called APPs $\alpha$, which is soluble under certain conditions [47] and a fragment of the carboxyl terminal portion (C83) [48]. The APPsa is found in lower quantities in AD patients [49] and has been associated with trophic and neuroprotective functions [50].

In patients with $\mathrm{AD}$, the first $\mathrm{APP}$ rupture at an extracellular level, generates a shorter soluble amino terminal portion (APPs $\beta$ ) and a longer terminal carboxyl fragment (C99) $[51,52]$. This split is performed mainly by BACE1 ( $\beta$ - site - APP - cleaving enzyme), an ubiquitous transmembrane protease with $\beta$-secretase activity. BACE1 expression can be modulated by frequently seen situations in neurodegenerative diseases and aging such as OS, ischemia, inflammation, hypoxia, and trauma [51, 53-55].

After $\gamma$-secretase, consisting of a heteromeric complex of 4 subunits called: presenilins (PSEN1 and PSEN2), nicastrin (NCSTN), APH-1, from the acronym anterior pharynx defensive phenotype 1 (APH-1a and APH-1b) and PEN - 2 (PS-enhancer-2) [56] produces a cut in the $\gamma$ site releasing the carboxyl terminal fragment named APP intracellular domain (AICD) and producing the amyloid $\beta$ peptide, which is secreted, aggregated, and accumulated in extracellular plaques due to its low solubility (Fig. 2) [57]. It has been observed that APH-1 inhibits the production of amyloid $\beta$ peptide while the PEN-2 favors it $[58,59]$.

Several studies have shown the in vitro and in vivo neurotoxicities of various forms of amyloid $\beta$ [60]; however, the exact mechanisms are quite complex and not fully understood $[37,52]$. So far the relation between the specific site of action of amyloid $\beta$ and its structural diversity is unknown; what is clear is that the amino acid sequence that is contained between positions 25 and 35 of the primary structure has greater neurotoxicity.

Concentrations of amyloid $\beta$ peptide are determined by the balance between generation and clearance; in $\mathrm{AD}$ 
patients, a clearance abnormality leads to the accumulation of amyloid $\beta$ in the brain [61]. The transport of amyloid $\beta$ through the blood-brain barrier is mediated by receptors, the passage of the peptide from the brain to the blood occurs by interaction with LRP-1 receptors (Lipoprotein receptor-related protein-1) and the action of $\mathrm{p}$ glycoproteins. Increased levels of amyloid $\beta$ and aging, decrease of the expression of LRP-1 receptors results in an accumulation of amyloid peptide in the central nervous system (CNS).

The transit of amyloid $\beta$ peptide into the brain through the blood-brain barrier [62] also occurs via receptors, primarily through multi-ligand AGE (advanced glycation end products) receptors or RAGE. RAGE expression is determined by the concentration of its own ligands. In contrast to the expression decrease of LPR-1s due to high levels of amyloid $\beta$ in the brain, RAGE increases the expression under these conditions.

Since RAGE interaction with amyloid $\beta$ causes: inflammatory responses at the endothelium level, endothelial cell apoptosis, decreased cerebral blood flow, and suppression of LTP; RAGE may play a role in the development of neurovascular changes observed in $\mathrm{AD}$ [6265].

Proteolytic degradation of amyloid $\beta$ peptide is carried out mainly by neprilysin (NEP) and the insulindegrading enzyme (IDE). During aging and in AD patients, the expression of NEP and IDE decreases, causing an increase in the concentration of amyloid $\beta$ peptide in the brain $[61,66]$. In patients with $\mathrm{AD}$, decreased quantity and activity of NEP is seen especially in the cortex and hippocampus, but not in other regions of the brain.

The secretion of IDE in the brain is regulated by the microglia, and similar to NEP its distribution and concentration also presents differences in AD patients. Lower concentrations have been identified in the cortex and hippocampus, where the predominant form has a higher degree of oxidation [9].

The endosomal lysosomal pathway is also an important regulator of the processing of APP $[67,68]$ and of the tau protein metabolism [69]. Because of the importance of this pathway for cellular maintenance and its role in the immune system, recent studies suggest that dysfunctions in neuronal autophagy causing an increase in the amount and size of endosomes at the cellular level, may be involved in the pathogenesis of $\mathrm{AD}$ [70-74], as these changes are seen before the appearance of senile plaques and neurofibrillary tangles in the brain $[72,74]$. Other studies report the absence of a di- rect relationship between quantity and size of lysosomes and $\mathrm{AD}$ [75].

The amyloid cascade hypothesis has the highest acceptance rate; however, current studies support the idea that not only amyloid $\beta$ but other fragments from the processing of APP, such as C83 or AICD, contribute to the pathogenesis of $\mathrm{AD}$ resulting in difficulty to attribute the pathological features of the disease exclusively to the amyloid peptide [60].

\section{The Tau ( $\tau$ ) Protein}

The amyloid cascade hypothesis consists of the production and accumulation of amyloid $\beta$ peptide as the beginning of the disease process; however, it does not completely explain the etiopathogenesis of $\mathrm{AD}$. In this hypothesis, the $\tau$ protein arises as a secondary pathogenic event that subsequently causes neurodegeneration $[76,77]$. In vitro experiments using various cell types, ranging from neuronal cell lines to primary hippocampal and cortical neurons and hippocampal organotypic cultures, have demonstrated that amyloid $\beta$ induces $\tau$-alterations [78-80]. These include mainly an increased phosphorylation and cytoplasmic and dendritic translocation often linked to neurodegeneration [81].

The $\tau$ protein is a highly soluble protein that relates to the microtubules and its function under normal conditions consists of stabilizing them. These microtubules provide support for structural changes, axonal transport, and neuronal growth $[69,82,83]$. In the CNS, the $\tau$ protein presents itself in 6 different isoforms that vary in the number of binding sites for microtubules and the amount of exons they possess [82]. In AD, dysfunctions occur in phosphorylation processes of $\tau$ protein, resulting in a hyperphosphorylation of the molecule.

Hyperphosphorylated protein $\tau$ presents aberrant aggregation with the cytoskeletal proteins; it shows a lower grade of interaction with microtubules which favors an increase of free tau protein that leads to greater aggregation and fibrillization of itself, with the consequent malfunction of axonal transport $[84,85]$.

Scientific literature reports changes in $\tau$ protein and amyloid $\beta$ oligomers as the most important factors responsible for neuronal dysfunction in the pathogenesis of AD $[46,86]$. Likewise neurofibrillary tangles observed initially in the EC and hippocampus subsequently extend to the amygdala and cortical areas (temporal, frontal, and parietal) $[57,85]$.
Ann Neurosci 2017;24:46-54 DOI: $10.1159 / 000464422$
Sanabria-Castro/Alvarado-Echeverría/ Monge-Bonilla 


\section{Contribution of OS in the Pathogenesis of AD}

It has been long recognized that one of the common characteristics in neurodegenerative diseases is the relationship between OS and neuronal apoptosis [87]. OS is a condition in which the balance between production of active reactive oxygen species (ROS) and the level of antioxidants is significantly disturbed, resulting in cell damage. ROS chemically interact with biological molecules such as nucleic acids, proteins and lipids, and cell organelles [88].

In addition to the established pathology of senile plaques and neurofibrillary tangles, the presence of extensive $\mathrm{OS}$ is a characteristic of $\mathrm{AD}$ brains. The accumulation of free radical damage, alterations in the activities or expression of antioxidant enzymes such as superoxide dismutase and catalase are also present in $\mathrm{AD}$ patients [89]. Although OS is an important factor in AD pathogenesis, the mechanisms by which the redox balance is altered and the sources of free radicals are not exactly known. It has been demonstrated that abnormal accumulation of amyloid $\beta$ is capable of promoting the formation of ROS through a mechanism that involves the activation of NMDA receptors [90], and that OS may augment amyloid $\beta$ production and aggregation as well facilitate tau phosphorylation and polymerization, forming a vicious cycle that promotes the initiation and progression of $\mathrm{AD}$ [91].

Neuronal mitochondria (essential for cellular metabolism) show metabolic abnormalities in $\mathrm{AD}$ models. It has been demonstrated that mitochondria are quite vulnerable to OS, which may directly disrupt its functions (energy production, decrease of antioxidant enzymes, and loss of membrane potential), generating a further increase in ROS levels that finally produce cell death by caspase activation and apoptosis [9294].

\section{Calcium Homeostasis in AD}

Calcium, an ubiquitous intracellular messenger, regulates multiple physiological functions, generating concentration gradients and binding to several proteins, receptors, and ion channels. The regulation of intracellular calcium homeostasis is a very complex mechanism that is vital for several cellular pathways and is thus involved in cell survival and death. Two organelles play a major role in calcium homeostasis, the endoplasmic reticulum (ER) and mitochondria, whereas ATPase calcium pump and the sodium-calcium exchanger are the 2 main systems involved in calcium efflux through the plasma membrane $[95,96] . \mathrm{Ca}^{2+}$ is continuously exchanged between the cytosol and the lumen of the ER. Overload of intracellular calcium due to a blockage or dysfunction of the transport system leads to the cleavage of several proteins and other substrates, OS, perturbs energy production [97], stimulates protein production (amyloid $\beta$ and $\tau$ protein) [98], and induces cell death through necrosis and/or apoptosis $[99,100]$.

In $\mathrm{AD}$, the ability of neurons to regulate the influx, efflux, and subcellular compartmentalization of calcium is compromised [101]. These disruptions involve several mechanisms, such as alterations of calcium buffering capacities, deregulation of calcium channel activities, excitotoxicity or disruption of mitochondrial functions. Alterations resulting from calcium disruption are the result of age-related OS, metabolic impairment in combination with disease-related accumulation of $A \beta$ oligomers and the presence of mutations of genes that encode presenilin [102]. Particularly, A $\beta$ may promote cellular calcium overload by inducing membrane-associated OS and forming pores in the membrane [103105].

\section{Conclusion}

During the last decades, advances in cellular biology have been essential for understanding the molecular mechanisms underlying AD. Currently it is known that the molecular pathogenesis of $\mathrm{AD}$ is complex and involves several theories or hypothesis where many diverse factors interrelate. However, none of these postulates alone is able to clarify the entire aspect regarding the pathology, and further studies are required. Aspects like the initial causes of the disease such as the abnormal formation of amyloid $\beta$, and the mechanisms by which it affects neurons and nicotinic acetylcholine receptors and the relation between the disruption of cholinergic pathways and the cognitive deficits of AD are still not fully understood.

New discoveries that contribute to the elucidation of the molecular pathogenesis of $\mathrm{AD}$ and its relations are crucial because they can allow the development of new therapeutic strategies for the treatment of a condition where current drug therapy lacks the ability to prevent its occurrence and progression. 


\section{References}

1 Alzheimer A: Über einen eigenartigen schweren erkrankungsproze $\beta$ der hirnrincle. Neurol Cent 1906;25:1134.

2 Terry AV Jr, Buccafusco JJ: The cholinergic hypothesis of age and Alzheimer's disease-related cognitive deficits: recent challenges and their implications for novel drug development. J Pharmacol Exp Ther 2003;306:821827.

3 Schaeffer EL, Gattaz WF: Cholinergic and glutamatergic alterations beginning at the early stages of Alzheimer disease: participation of the phospholipase A2 enzyme. Psychopharmacology (Berl) 2008;198:1-27.

4 Watanabe S, Kato I, Koizuka I: Retrograde-labeling of pretecto-vestibular pathways in cats. Auris Nasus Larynx 2003;30(suppl):S35-S40.

5 Liskowsky W, Schliebs R: Muscarinic acetylcholine receptor inhibition in transgenic Alzheimer-like Tg2576 mice by scopolamine favours the amyloidogenic route of processing of amyloid precursor protein. Int J Dev Neurosci 2006;24:149-156.

6 Li Y, Yuan X, Shen Y, Zhao J, Yue R, Liu F, et al: Bacopaside I ameliorates cognitive impairment in APP/PS1 mice via immune-mediated clearance of $\beta$-amyloid. Aging (Albany NY) 2016;8:521-533.

7 Saraf MK, Anand A, Prabhakar S: Scopolamine induced amnesia is reversed by Bacopa monniera through participation of kinaseCREB pathway. Neurochem Res 2010;35 279-287.

8 Saraf MK, Prabhakar S, Khanduja KL, Anand A: Bacopa monniera attenuates scopolamineinduced impairment of spatial memory in mice. Evid Based Complement Alternat Med 2011;2011:236186.

9 Caccamo A, Oddo S, Billings LM, Green KN, Martinez-Coria H, Fisher A, et al: M1 receptors play a central role in modulating AD-like pathology in transgenic mice. Neuron 2006; 49:671-682

10 Fisher A: M1 muscarinic agonists target major hallmarks of Alzheimer's disease - an update. Curr Alzheimer Res 2007;4:577-580.

11 Fisher A, Medeiros R, Barner N, Natan N, Brandeis R, Elkon $\mathrm{H}$, et al: M1 muscarinic agonists and a multipotent activator of sigmal/ M1 muscarinic receptors: future therapeutics of Alzheimer's disease. Alzheimers Demen 2014; 10:P123.

12 Fisher A: M1 muscarinic agonists target major hallmarks of Alzheimer's disease - the pivotal role of brain $\mathrm{M} 1$ receptors. Neurodegener Dis 2008;5:237-240.

13 Ellis JR, Ellis KA, Bartholomeusz CF, Harrison BJ, Wesnes KA, Erskine FF, et al: Muscarinic and nicotinic receptors synergistically modulate working memory and attention in humans. Int J Neuropsychopharmacol 2006; 9:175-189.

14 Ringman JM, Cummings JL: Current and emerging pharmacological treatment options for dementia. Behav Neurol 2006;17:5-16.
15 Wu J, Ishikawa M, Zhang J, Hashimoto K: Brain imaging of nicotinic receptors in $\mathrm{Al}$ zheimer's disease. Int J Alzheimers Dis 2010; 2010:548913.

16 Wenk GL: Neuropathologic changes in Alzheimer's disease: potential targets for treatment. J Clin Psychiatry 2006;67(suppl 3):3-7; quiz 23.

17 Mesulam M: The cholinergic lesion of $\mathrm{Al}$ zheimer's disease: pivotal factor or side show? Learn Mem 2004; 11:43-49.

18 Shen J, Wu J: Nicotinic cholinergic mechanisms in Alzheimer's disease. Int Rev Neurobiol 2015;124:275-292.

19 Ni R, Marutle A, Nordberg A: Modulation of a7 nicotinic acetylcholine receptor and fibrillar amyloid- $\beta$ interactions in Alzheimer's disease brain. J Alzheimers Dis 2013;33:841851.

20 Dong XX, Wang Y, Qin Z: Molecular mechanisms of excitotoxicity and their relevance to pathogenesis of neurodegenerative diseases. Acta Pharmacol Sin 2009;30:379387.

21 Lin H, Vicini S, Hsu FC, Doshi S, Takano H, Coulter DA, et al: Axonal a 7 nicotinic ACh receptors modulate presynaptic NMDA receptor expression and structural plasticity of glutamatergic presynaptic boutons. Proc Natl Acad Sci U S A 2010;107:16661-16666.

22 Geerts H, Grossberg GT: Pharmacology of acetylcholinesterase inhibitors and N-methyl-D-aspartate receptors for combination therapy in the treatment of Alzheimer's disease. J Clin Pharmacol 2006;46(7 suppl 1):8S$16 \mathrm{~S}$.

23 Mohandas E, Rajmohan V, Raghunath B: Neurobiology of Alzheimer's disease. Indian J Psychiatry 2009;51:55.

24 Lynch MA: Long-term potentiation and memory. Physiol Rev 2004;84:87-136.

25 Beck J, Lenart B, Kintner DB, Sun D: Na-K-Cl cotransporter contributes to glutamate-mediated excitotoxicity. J Neurosci 2003;23:50615068.

26 Friedman LK: Calcium: a role for neuroprotection and sustained adaptation. Mol Interv 2006;6:315-329.

27 Szado T, Vanderheyden V, Parys JB, De Smedt H, Rietdorf K, Kotelevets L, et al: Phosphorylation of inositol 1,4,5-trisphosphate receptors by protein kinase B/Akt inhibits $\mathrm{Ca} 2+$ release and apoptosis. Proc Natl Acad Sci U S A 2008; 105:2427-2432.

28 Fan MMY, Raymond LA: N-methyl-D-aspartate (NMDA) receptor function and excitotoxicity in Huntington's disease. Prog Neurobiol 2007;81:272-293.

29 Navarro A, Boveris A: The mitochondrial energy transduction system and the aging process. Am J Physiol Cell Physiol 2007;292: C670-C686.

30 Jung KH, Chu K, Lee ST, Park HK, Kim JH, Kang KM, et al: Augmentation of nitrite therapy in cerebral ischemia by NMDA receptor inhibition. Biochem Biophys Res Commun 2009;378:507-512.

31 Ndountse LT, Chan HM: Role of N-methyl$\mathrm{D}$-aspartate receptors in polychlorinated biphenyl mediated neurotoxicity. Toxicol Lett 2009; 184:50-55.

32 Snyder EM, Nong Y, Almeida CG, Paul S, Moran T, Choi EY, et al: Regulation of NMDA receptor trafficking by amyloid-beta. Nat Neurosci 2005;8:1051-1058.

33 Parameshwaran K, Dhanasekaran M, Suppiramaniam V: Amyloid beta peptides and glutamatergic synaptic dysregulation. Exp Neurol 2008;210:7-13.

34 Butterfield DA, Pocernich CB: The glutamatergic system and Alzheimer's disease: therapeutic implications. CNS Drugs 2003;17:641652.

35 Doraiswamy PM: Non-cholinergic strategies for treating and preventing Alzheimer's disease. CNS Drugs 2002;16:811-824.

36 Walton HS, Dodd PR: Glutamate-glutamine cycling in Alzheimer's disease. Neurochem Int 2007;50:1052-1066.

37 Peña F, Gutiérrez-Lerma A, Quiroz-Baez R, Arias C: The role of beta-amyloid protein in synaptic function: implications for Alzheimer's disease therapy. Curr Neuropharmacol 2006;4:149-163.

38 Doggrell SA, Evans S: Treatment of dementia with neurotransmission modulation. Expert Opin Investig Drugs 2003;12:1633-1654.

39 Cummings JL, Doody R, Clark C: Diseasemodifying therapies for Alzheimer disease: challenges to early intervention. Neurology 2007;69:1622-1634.

40 Deane R, Bell RD, Sagare A, Zlokovic BV Clearance of amyloid-beta peptide across the blood-brain barrier: implication for therapies in Alzheimer's disease. CNS Neurol Disord Drug Targets 2009;8:16-30.

41 Jucker M, Walker LC: Neurodegeneration: amyloid- $\beta$ pathology induced in humans. $\mathrm{Na}$ ture 2015;525:193-194.

42 McGowan E, Pickford F, Kim J, Onstead L, Eriksen J, Yu C, et al: Abeta42 is essential for parenchymal and vascular amyloid deposition in mice. Neuron 2005;47:191-199.

43 Bertram L, Tanzi RE: Thirty years of Alzheimer's disease genetics: the implications of systematic meta-analyses. Nat Rev Neurosci 2008;9:768-778.

44 Wu LG, Saggau P: Presynaptic inhibition of elicited neurotransmitter release. Trends Neurosci 1997;20:204-212.

45 Leão RN, Colom LV, Borgius L, Kiehn O, Fisahn A: Medial septal dysfunction by $A \beta$ induced KCNQ channel-block in glutamatergic neurons. Neurobiol Aging 2012;33:2046-2061.

46 De Strooper B: Proteases and proteolysis in Alzheimer disease: a multifactorial view on the disease process. Physiol Rev 2010;90:465-494.

47 Tanzi RE, Bertram L: Twenty years of the Alzheimer's disease amyloid hypothesis: a genetic perspective. Cell 2005;120:545-555. 
48 Lichtenthaler SF, Haass C: Amyloid at the cutting edge: activation of alpha-secretase prevents amyloidogenesis in an Alzheimer disease mouse model. J Clin Invest 2004;113: 1384-1387.

49 Sennvik K, Fastbom J, Blomberg M, Wahlund LO, Winblad B, Benedikz E: Levels of alphaand beta-secretase cleaved amyloid precursor protein in the cerebrospinal fluid of Alzheimer's disease patients. Neurosci Lett 2000;278: 169-172.

50 Puzzo D, Privitera L, Leznik E, Fà M, Staniszewski A, Palmeri A, et al: Picomolar amyloidbeta positively modulates synaptic plasticity and memory in hippocampus. J Neurosci 2008;28:14537-14545.

51 Velliquette RA, O’Connor T, Vassar R: Energy inhibition elevates beta-secretase levels and activity and is potentially amyloidogenic in APP transgenic mice: possible early events in Alzheimer's disease pathogenesis. J Neurosci 2005;25:10874-10883.

52 Siegel GS, Chauhan N, Karczmar AG: Links between Amyloid and Tau Biology in $\mathrm{Al}$ zheimer's Disease and Their Cholinergic Aspects. Exploring the Vertebrate Central Cholinergic Nervous System. New York, 2007, pp 597-603.

53 Wen Y, Onyewuchi O, Yang S, Liu R, Simpkins JW: Increased beta-secretase activity and expression in rats following transient cerebral ischemia. Brain Res 2004;1009:1-8.

54 Bourne KZ, Ferrari DC, Lange-Dohna C, Rossner S, Wood TG, Perez-Polo JR: Differential regulation of $\mathrm{BACE} 1$ promoter activity by nuclear factor-kappaB in neurons and glia upon exposure to beta-amyloid peptides. J Neurosci Res 2007;85:1194-1204.

55 Zhang X, Zhou K, Wang R, Cui J, Lipton SA, Liao FF, et al: Hypoxia-inducible factor 1alpha (HIF-1alpha)-mediated hypoxia increases BACE1 expression and beta-amyloid generation. J Biol Chem 2007;282:10873-10880.

56 De Strooper B: Aph-1, Pen-2, and Nicastrin with Presenilin generate an active gammaSecretase complex. Neuron 2003;38:9-12.

57 Goedert M, Spillantini MG: A century of Alzheimer's disease. Science 2006;314:777-781.

58 Seo SJ, Hwang DY, Cho JS, Chae KR, Kim CK, Shim SB, et al: PEN-2 overexpression induces gamma-secretase protein and its activity with amyloid beta- 42 production. Neurochem Res 2007;32:1016-1023.

59 Uemura K, Lill CM, Li X, Peters JA, Ivanov A, Fan Z, et al: Allosteric modulation of PS1/ gamma-secretase conformation correlates with amyloid beta(42/40) ratio. PLoS One 2009;4:e7893.

60 Simon A, Frechilla D, del Río J: Perspectivas sobre la hipótesis de la cascada del amiloide en la enfermedad de Alzheimer. Rev Neurol 2010;50:667-675.

61 Wang DS, Dickson DW, Malter JS: Beta-amyloid degradation and Alzheimer's disease. J Biomed Biotechnol 2006;2006:58406.

62 Chen X, Walker DG, Schmidt AM, Arancio O, Lue LF, Yan SD: RAGE: a potential target for Abeta-mediated cellular perturbation in Alzheimer's disease. Curr Mol Med 2007;7: 735-742.

63 McGeer PL, Rogers J, McGeer EG: Inflammation, anti-inflammatory agents and Alzheimer disease: the last 12 years. J Alzheimers Dis 2006;9(3 suppl):271-276.

64 Origlia N, Righi M, Capsoni S, Cattaneo A Fang F, Stern DM, et al: Receptor for advanced glycation end product-dependent activation of p38 mitogen-activated protein kinase contributes to amyloid-beta-mediated cortical synaptic dysfunction. J Neurosci 2008;28:3521-3530.

65 Aisen PS: Alzheimer's disease therapeutic research: the path forward. Alzheimers Res Ther 2009;1:2.

66 Miners JS, Baig S, Tayler H, Kehoe PG, Love $S$ : Neprilysin and insulin-degrading enzyme levels are increased in Alzheimer disease in relation to disease severity. J Neuropathol Exp Neurol 2009;68:902-914

67 Grbovic OM, Mathews PM, Jiang Y, Schmidt $\mathrm{SD}$, Dinakar R, Summers-Terio NB, et al: Rab5-stimulated up-regulation of the endocytic pathway increases intracellular betacleaved amyloid precursor protein carboxylterminal fragment levels and Abeta production. J Biol Chem 2003;278:31261-31268.

68 Pasternak SH, Callahan JW, Mahuran DJ: The role of the endosomal/lysosomal system in amyloid-beta production and the pathophysiology of Alzheimer's disease: reexamining the spatial paradox from a lysosomal perspective. J Alzheimers Dis 2004;6:53-65.

69 Funderburk SF, Marcellino BK, Yue Z: Cell "self-eating" (autophagy) mechanism in Alzheimer's disease. Mt Sinai J Med 2010;77: 59-68.

70 Komatsu M, Waguri S, Chiba T, Murata S, Iwata J, Tanida I, et al: Loss of autophagy in the central nervous system causes neurodegeneration in mice. Nature 2006;441:880884.

71 Hara T, Nakamura K, Matsui M, Yamamoto A, Nakahara Y, Suzuki-Migishima R, et al: Suppression of basal autophagy in neural cells causes neurodegenerative disease in mice. Nature 2006;441:885-889.

72 Boland B, Kumar A, Lee S, Platt FM, Wegiel $\mathrm{J}, \mathrm{Yu} \mathrm{WH}$, et al: Autophagy induction and autophagosome clearance in neurons: relationship to autophagic pathology in Alzheimer's disease. J Neurosci 2008;28:6926-6937.

73 Rusten TE, Simonsen A: ESCRT functions in autophagy and associated disease. Cell Cycle 2008;7:1166-1172.

74 Nixon RA: Autophagy, amyloidogenesis and Alzheimer disease. J Cell Sci 2007;120(pt 23): 4081-4091.

75 Helmfors L, Boman A, Civitelli L, Nath S, Sandin L, Janefjord C, et al: Protective properties of lysozyme on $\beta$-amyloid pathology: Implications for Alzheimer disease. Neurobiol Dis 2015;83:122-133.

76 Fuentes GP, Slachevsky CA: Enfermedad de Alzheimer: actualización en terapia farmacológica. Rev Med Chil 2005;133: 224-230.

77 Roberson ED, Scearce-Levie K, Palop JJ, Yan $\mathrm{F}$, Cheng $\mathrm{IH}, \mathrm{Wu}$ T, et al: Reducing endogenous tau ameliorates amyloid beta-induced deficits in an Alzheimer's disease mouse model. Science 2007;316:750-754.

78 Wang HY, Li W, Benedetti NJ, Lee DH: Alpha 7 nicotinic acetylcholine receptors mediate beta-amyloid peptide-induced tau protein phosphorylation. J Biol Chem 2003;278: 31547-31553.

79 Zheng WH, Bastianetto S, Mennicken F, Ma W, Kar S: Amyloid beta peptide induces tau phosphorylation and loss of cholinergic neurons in rat primary septal cultures. Neuroscience 2002;115:201-211.

80 Götz J, Chen F, van Dorpe J, Nitsch RM: Formation of neurofibrillary tangles in P301l tau transgenic mice induced by Abeta 42 fibrils. Science 2001;293:1491-1495.

81 Stancu IC, Vasconcelos B, Terwel D, Dewachter I: Models of $\beta$-amyloid induced Taupathology: the long and "folded" road to understand the mechanism. Mol Neurodegener 2014;9:51.

82 Goedert M, Klug A, Crowther RA: Tau protein, the paired helical filament and Alzheimer's disease. J Alzheimers Dis 2006;9(3 suppl): 195-207.

83 Citron M: Alzheimer's disease: strategies for disease modification. Nat Rev Drug Discov 2010;9:387-398.

84 Kuret J, Congdon EE, Li G, Yin H, Yu X, Zhong Q: Evaluating triggers and enhancers of tau fibrillization. Microsc Res Tech 2005; 67:141-155.

85 Rafii MS, Aisen PS: Recent developments in Alzheimer's disease therapeutics. BMC Med 2009;7:7.

86 Stoothoff WH, Johnson GV: Tau phosphorylation: physiological and pathological consequences. Biochim Biophys Acta 2005; 1739: 280-297.

87 Lin MT, Beal MF: Mitochondrial dysfunction and oxidative stress in neurodegenerative diseases. Nature 2006;443:787-795.

88 Gandhi S, Abramov AY: Mechanism of oxidative stress in neurodegeneration. Oxid Med Cell Longev 2012;2012:428010.

89 Praticò D: Oxidative stress hypothesis in $\mathrm{Al}$ zheimer's disease: a reappraisal. Trends Pharmacol Sci 2008;29:609-615.

90 Makhaeva GF, Lushchekina S V, Boltneva NP, Sokolov VB, Grigoriev VV, Serebryakova OG, et al: Conjugates of $\gamma$-carbolines and phenothiazine as new selective inhibitors of butyrylcholinesterase and blockers of NMDA receptors for Alzheimer disease. Sci Rep 2015; 5:13164.

91 Zhao Y, Zhao B: Oxidative stress and the pathogenesis of Alzheimer's disease. Oxid Med Cell Longev 2013;2013:316523.

92 Grivennikova VG, Vinogradov AD: Generation of superoxide by the mitochondrial Complex I. Biochim Biophys Acta 2006;1757: 553-561. 
93 Hirai K, Aliev G, Nunomura A, Fujioka H, Russell RL, Atwood CS, et al: Mitochondrial abnormalities in Alzheimer's disease. J Neurosci 2001;21:3017-3023.

94 Zhu X, Perry G, Moreira PI, Aliev G, Cash AD, Hirai K, et al: Mitochondrial abnormalities and oxidative imbalance in Alzheimer disease. J Alzheimers Dis 2006;9: 147-153.

95 Korol' TY, Korol' SV, Kostyuk EP, Kostyuk PG: Disruption of calcium homeostasis in Alzheimer's disease. Neurophysiology 2008;40: 385-392.

96 Magi S, Castaldo P, Macrì ML, Maiolino M, Matteucci A, Bastioli G, et al: Intracellular calcium dysregulation: implications for $\mathrm{Al}$ zheimer's disease. Biomed Res Int 2016;2016: 6701324.
97 Fonseca AC, Cardoso SM, Pereira CF: Calcium and redox homeostasis in $\mathrm{Al}$ zheimer's disease: a focus on the endoplasmic reticulum. Ther Targets Neurol Dis 2014;1:1-13.

98 Stutzmann GE, Caccamo A, LaFerla FM, Parker I: Dysregulated IP3 signaling in cortical neurons of knock-in mice expressing an Alzheimer's-linked mutation in presenilin1 results in exaggerated $\mathrm{Ca} 2+$ signals and altered membrane excitability. J Neurosci 2004;24:508-513.

99 Hagenston AM, Rudnick ND, Boone CE, Yeckel MF: 2-Aminoethoxydiphenyl-borate (2-APB) increases excitability in pyramidal neurons. Cell Calcium 2009;45:310-317.

100 Small DH: Dysregulation of calcium homeostasis in Alzheimer's disease. Neurochem Res 2009;34:1824-1829.

101 Wang JM, Sun C: Calcium and neurogenesis in Alzheimer's disease. Front Neurosci 2010; 4:194.
102 Green KN, Smith IF, Laferla FM: Role of calcium in the pathogenesis of Alzheimer's disease and transgenic models. Subcell Biochem 2007;45:507-521.

103 Arispe N, Rojas E, Pollard HB: Alzheimer disease amyloid beta protein forms calcium channels in bilayer membranes: blockade by tromethamine and aluminum. Proc Nat Acad Sci U S A 1993;90:567-571.

104 Crompton M, Barksby E, Johnson N, Capano M: Mitochondrial intermembrane junctional complexes and their involvement in cell death. Biochimie 2002; 84:143-152.

105 Giorgio V, Soriano ME, Basso E, Bisetto E, Lippe G, Forte MA, et al: Cyclophilin D in mitochondrial pathophysiology. Biochim Biophys Acta 2010;1797:1113-1118. 